\title{
Restorative Therapies after Stroke: Drugs, Devices and Robotics
}

\author{
MV Padma Srivastava \\ Department of Neurology \\ All India Institute of Medical Sciences, New Delhi.
}

\begin{abstract}
Restorative therapies aim to improve outcome and function by promoting plasticity within a therapeutic time window between days to weeks to years. In this article, the mechanisms by which cell-based, pharmacological and robotic treatments stimulate endogenous brain remodelling after stroke, particularly neurogenesis, axonal plasticity and white-matter integrity are described with a brief outline of the potential of neuroimaging (fMRI) techniques. Stem cells aid stroke recovery via mechanisms depending on the type of cells used. Transplanted embryonic stem cells (ESCs), induced pluripotent stem cells (iPSCs), and neural stem cells (NSCs) can replace the missing brain cells in the Infarcted area, while adult stem cells, such as mesenchymal stem cells or multipotent stromal cells (MSCs) and MNCs, provide trophic support to enhance self-repair systems such as endogenous neurogenesis. Most preclinical studies of stem cell therapy for stroke have emphasized the need to enhance self-repair systems rather than to replace lost cells, regardless of the type of cells used. Noninvasive brain stimulation (NIBS) provides a valuable tool for interventional neurophysiology by modulating brain activity in a specific distributed, cortico-subcortical network. The two most commonly used techniques for noninvasive brain stimulation are transcranial magnetic stimulation (TMS) and transcranial direct current stimulation (tDCS). The article also discusses the potential role and current evidence for the use of pharmacological therapy, robotics and specific forms of physiotherapy regimes in optimizing stroke recovery. Neurorestoration is a concept that has been proven emphatically in several experimental models and clinical studies of stroke. Elucidating the underlying mechanisms of cell-based, pharmacological and rehabilitative therapies is of primary interest and crucial for translation of treatments to clinical use. The knowledge must provide an impetus for the development of superior, advanced and cost effective neuro restorative interventions that will enhance stroke recovery.
\end{abstract}

Keywords : Cerebral stroke, stroke therapy, functional neuroimaging.

Correspondence: Dr. MV Padma Srivastava, Professor, Head Unit II Neurology, All India Institute of Medical Sciences, Ansari Nagar, Ring Road, New Delhi - 110029. E-mail: vasanthapadma123@gmail.com. Mob:9868398261. 


\section{Introduction}

Stroke is the second leading cause of mortality and morbidity with approximately half of them dependent on care givers resulting in significant health care costs (1). Neuroprotection in the form of thrombolytic therapy is an inherent treatment for ischemia with only $5.2 \%$ receiving treatment in the window period (2). Acute stroke interventions for hemorrhagic stroke are limited. After much research focussed on acute neuroprotection, the National Institute of Neurological Disease and Stroke (NINDS) progress review group in 2006 and 2011 identified neurorestoration after stroke as a major priority for stroke research (3).

Restorative therapies aim to improve outcome and function by promoting plasticity within a therapeutic time window between days to weeks to years vis-a-vis reperfusion or neuroprotective drugs which act on salvageable brain (4). The aforementioned armamentarium includes growth factors, cell-based therapies, drugs and devices. Pharmacological treatment includes drugs that increase cGMP (e.g. phosphodiesterase 5 inhibitors, such as sildenafil and tadalafil), statins, erythropoietin, granulocyte-colony stimulating factor and minocycline (5).

There is an unmet need to design and improvise newer interventions to help patients repair and return to normal function. In this article, the mechanisms by which cell-based, pharmacological and robotic treatments stimulate endogenous brain remodelling after stroke, particularly neurogenesis, axonal plasticity and white-matter integrity are described with a brief outline of the potential of neuroimaging (fMRI) techniques (6).

\section{Brain Insult: Repair and Recovery}

The injury and recovery mechanisms after stroke have been extensively studied. The first epoch is related to acute injury and takes place in the first initial hours after stroke when changes in blood flow, edema, metabolism rate and diaschisis occur. A second epoch is related to repair, which starts days after stroke and lasts for several weeks and is referred to as endogenous repair suggesting a golden period for initiating restorative therapies. A third epoch occurs weeks to months after stroke when spontaneous recovery gains have plateaued with residual deficits which may or may not be modifiable (7, 8).

\section{Cell-based Interventions :Stem Cells}

Stem cells can be defined as clonogenic cells that have the capacity to self-renew and differentiate into multiple cell lineages. They are divided according to the body's development process and their ability to form other cells (9). Totipotent stem cells are capable of giving rise to an entire organism and can be derived from fertilized oocytes and cells of the developing zygote up to the eighth cell stage. They have the potential to differentiate into derivatives of all germ layers (ectoderm, endoderm and mesoderm). Pluripotent stem cells can give rise to all tissue types, from any of the three embryonic germ layers, but unlike totipotent cells cannot give rise to an entire organism (10). These cells can give rise to different types of cells representing derivatives of two different germ layers, e.g. skin (ectoderm) and muscle (mesoderm). Multipotent stem cells are able to differentiate into multiple types of cells, but within one organ system (e.g. blood) (11). Progenitor cells differentiate into mature cells (e.g. endothelial progenitor cells) and can only divide a limited number of times, are laid between stem cells and fully differentiated cells (12-14).

The omnipresent nature of these cells, their clear role in neural tissue development, their presumed participation in repair and regeneration and the irrefutable success of bone marrow stem cell therapy have raised high expectations to cure diseases that have thus far proven resistant to conventional therapy such as 
stroke $(15,16)$. The success of "bench to bedside" of cell transplantation in the last decade has seen a spurt of stem cell research in various pathological disorders, albeit all such clinical studies are/were phase $1 / 2$ which aimed at safety and feasibility of cells.

\section{Human Umbilical Cord Blood Cells (UCB)}

These cells are derived from umbilical cord blood with a wonderous potential of differentiation into neural lineages (17). When exposed to nerve growth factor and retinoic acid, the derived umbilical cord blood cells produce progeny that shows positivity of neural and glial cells markers. A better understanding of these cells is needed before clinical transplantation studies ensue, although experimental data in animal models of stroke have shown functional benefits $(18,19)$. However, biology of these cells is poorly understood, and it is likely that positive effects of these cells are related to their neurotrophic action, rather than actual neuronal circuitry formation.

\section{Immortalised Cell Lines}

These cell lines are derived by infecting neuroepithelial precursor cells from predefined $\mathrm{CNS}$ regions before terminal mitosis, with a retrovirus encoding an immortalizing oncogene view of the ethical difficulties in transplanting embryonic cells and technical problems in xenotransplantation, alternative sources of graft cells have been devised (20).

\section{Fetal Neural Stem Cells}

These cells maintain a normal karyotype for a significant number of passages in culture and can produce a large number of neurons and astrocytes and are harvested from the postmortem human fetal brain. These possess a relatively high proliferative capacity without any evidence of tumorogenesis following transplantation (21).

\section{Adult Neural Stem Cells (NSC)}

Adult stem cells are multipotent stem cells found in developed organisms, which are used to replace cells that have died or lost function (22). NSCs are defined as undifferentiated cells that are able to self - renew as well as generate three major cell types of CNS: neurons, astrocytes and oligodendrocytes, signifying their pluripotent nature (23). They have been identified within many different organ systems, including bone marrow, brain, heart, skin and bone. Adult stem cells make up $1-2 \%$ of the total cell population within a particular tissue type. They are usually quiescent and held in an undifferentiated state until they receive a stimulus to differentiate (24).

\section{Bone Marrow Derived Cells}

These have hematopoietic and nonhematopoietic component, the former being abundant in bone marrow (25). Mobilized Peripheral Blood (MPB) is also a clinical source of heme cells, containing a mixture of hematopoietic stem and progenitor cells enriched with CD34 (26,27). These cells have the potential to regenerate the brain tissue by release of neurotrophic growth hormones. The other component of bone marrow contains mesenchymal stem cells or multipotent stromal cells (MSCs) described as colony-forming units (CFUs) that adhere to cell culture surfaces and can be differentiated into osteoblasts, adipocytes and chondrocytes (28-30). MSCs secrete inter leukin-6 (IL-6), IL-7, IL-11, IL-12, leukemia inhibitory factor (LIF), macrophage-colony stimulating factor (M-CSF), stem cell factor (SCF) and flt-3ligand (31).

\section{Induced Pluripotent Stem Cells (iPSCs)}

These cells are similar to human embryonic stem cells (ESCs) in morphology, proliferation, surface antigens, gene expression, epigenetic status of pluripotent cell-specific genes and telomerase activity (32). Adult human cells from skin were transformed to a pluripotent state using genetic engineering 
Table : Clinical Trials of Stem Cells in Patient with Stroke

\begin{tabular}{|c|c|c|c|c|c|c|}
\hline Sr. No. & $\begin{array}{l}\text { Study design } \\
\text { control cell } \\
\text { group }\end{array}$ & $\begin{array}{l}\text { Characteristics of } \\
\text { stroke }\end{array}$ & $\begin{array}{l}\text { Manipulation } \\
\text { (cell done) }\end{array}$ & Route & Efficacy & Adverse effects \\
\hline \multicolumn{7}{|c|}{ Autologous bone marrow mononuclear cells } \\
\hline 1. & $\begin{array}{l}\text { None : } 5 \\
\text { patients 1-year } \\
f / u\end{array}$ & $\begin{array}{l}\text { Chronic Ischemic or } \\
\text { ICH }\end{array}$ & $\begin{array}{l}\text { Isolation using } \\
\text { normal saline }\end{array}$ & $\mathrm{IC}$ & N/A & None \\
\hline 2. & $\begin{array}{l}\text { None : } 6 \\
\text { patients } 6- \\
\text { month } f / u\end{array}$ & Subacute MCA infarct & $\begin{array}{l}\text { Isolation using } \\
\text { human albumin- } \\
\text { containing normal } \\
\text { saline }\left(0.6-5 \times 10^{2}\right)\end{array}$ & IA & N/A & $\begin{array}{l}\text { Seizure after } 200 \\
\text { days }\end{array}$ \\
\hline 3. & $\begin{array}{l}\text { None : } 10 \\
\text { patients } 6- \\
\text { month } f / u\end{array}$ & $\begin{array}{l}\text { Acute Large MCA } \\
\text { infarct }\end{array}$ & $\begin{array}{l}\text { Isolation using } \\
\text { human albumin- } \\
\text { containing normal } \\
\text { saline }\left(0.6-5 \times 10^{2}\right)\end{array}$ & IV & $\begin{array}{l}\text { Limited study } \\
\text { design }\end{array}$ & None \\
\hline 4. & $\begin{array}{l}\text { None : } 20 \\
\text { patients } 6- \\
\text { month } f / u\end{array}$ & $\begin{array}{l}\text { Acute Nonlacunar } \\
\text { infarct }\end{array}$ & $\begin{array}{l}\text { Isolation using } \\
\text { human albumin- } \\
\text { containing normal } \\
\text { saline }\left(0.6-5 \times 10^{2}\right)\end{array}$ & IA & $\begin{array}{l}\text { Limited study } \\
\text { design }\end{array}$ & None \\
\hline 5. & $\begin{array}{l}40: 60 \text { patients } \\
6 \text {-month } f / u\end{array}$ & Acute ICH & $\begin{array}{l}\text { Isolation using } \\
\text { normal saline } \\
\left(1.33 \times 10^{2}\right)\end{array}$ & $\mathrm{IC}$ & $\begin{array}{l}\text { NIHSS and BI } \\
\text { improved }\end{array}$ & None \\
\hline 6. & $60: 60$ patients & $\begin{array}{l}\text { Subacute MC/ACA } \\
\text { infarct }\end{array}$ & $\begin{array}{l}\text { Isolation using } \\
\text { normal saline } \\
\left(2.8 \times 10^{2}\right)\end{array}$ & IV & $\begin{array}{l}\text { B1 and } \mathrm{mRS} \text { at } \\
\text { day } 180\end{array}$ & $\begin{array}{l}\text { Similar in the two } \\
\text { groups }\end{array}$ \\
\hline \multicolumn{7}{|c|}{ Autologous bone marrow-derived mesenchymal stem cells } \\
\hline 7. & $\begin{array}{l}25: 5 \text { patients } \\
1-\text { year } f / u\end{array}$ & $\begin{array}{l}\text { Subacute Large MCA } \\
\text { infarct }\end{array}$ & $\begin{array}{l}\text { Ex vivo culture } \\
\text { expansion using } \\
\text { fetal bovine serum } \\
\left(1 \times 10^{2}\right)\end{array}$ & IV & $\begin{array}{l}\text { B1 improved at } \\
3 \text { months }\end{array}$ & None \\
\hline 8. & $\begin{array}{l}36: 16 \text { patients } \\
5 \text {-year } f / u\end{array}$ & $\begin{array}{l}\text { Subacute Large MCA } \\
\text { infarct }\end{array}$ & $\begin{array}{l}\text { Ex vivo culture } \\
\text { expansion using } \\
\text { fetal bovine serum } \\
\left(1 \times 10^{2}\right)\end{array}$ & IV & $\begin{array}{l}\text { mRS 0-3, } \\
\text { increased in } \\
\text { MSC group }\end{array}$ & None \\
\hline 9. & $\begin{array}{l}\text { None : } 12 \\
\text { patients } 1 \text {-year } \\
f / u\end{array}$ & $\begin{array}{l}\text { Subacute to chronic } \\
\text { Variable }\end{array}$ & $\begin{array}{l}\text { Ex vivo culture } \\
\text { expansion using } \\
\text { autologous serum } \\
\left(1 \times 10^{2}\right)\end{array}$ & IV & $\begin{array}{l}\text { Limited study } \\
\text { design }\end{array}$ & None \\
\hline 10. & $\begin{array}{l}\text { 6:6 patients } 24- \\
\text { week } f / u\end{array}$ & $\begin{array}{l}\text { Chronic Ischemic or } \\
\text { ICH }\end{array}$ & $\begin{array}{l}\text { Ex vivo culture } \\
\text { expansion using } \\
\text { serum-free media } \\
\left(5-6 \times 10^{2}\right)\end{array}$ & IV & $\begin{array}{l}\text { Modest increase } \\
\text { in FM and } \mathrm{mBI}\end{array}$ & None \\
\hline \multicolumn{7}{|c|}{ Allogeneic neural stem/progenitor cells } \\
\hline 11. & $\begin{array}{l}\text { None:5 patients } \\
\text { Terminated } \\
\text { early }\end{array}$ & $\begin{array}{l}\text { Chronic MCA infarct } \\
\text { affecting striatum }\end{array}$ & $\begin{array}{l}\text { Ex vivo culture } \\
\text { expansion of NSCs } \\
\text { obtained from } \\
\text { primordial porcine } \\
\text { striatum }\end{array}$ & $\mathrm{IC}$ & $\begin{array}{l}\text { Limited study } \\
\text { design }\end{array}$ & $\begin{array}{l}\text { Seizure, } \\
\text { aggravation of } \\
\text { hemiplegia }\end{array}$ \\
\hline 12. & $\begin{array}{l}\text { None: } 8 \text { patients } \\
2 \text {-year } f / u\end{array}$ & $\begin{array}{l}\text { Subacute to chronic } \\
\text { MCA/ACA infarct }\end{array}$ & $\begin{array}{l}\text { Ex vivo culture } \\
\text { expansion of NSCs } \\
\text { obtained from fetal } \\
\text { brain }\end{array}$ & $\mathrm{IC}$ & $\begin{array}{l}\text { Limited study } \\
\text { design }\end{array}$ & $\begin{array}{l}\text { Transient low- } \\
\text { grade fever only }\end{array}$ \\
\hline
\end{tabular}

ACA : anterior cerebral artery, B1 : Barthel index, FM : Meyer score, f/u : follow-up, IA : intra-arterial, IC : intra-cerebral, ICH : intra-cerebral hemorrhage, IV : intravenous, $\mathrm{mBI}:$ modified Barthel index, MCA : middle cerebral artery, mRS : modified Rankin Score, MSC : mesenchymal stem cell, N/A : not available, NIHSS : National Institutes of Health Stroke Scale, NSCs : neural stem/progenitor cells 
techniques which could help generate patient and disease specific cells.

Stem cells aid stroke recovery via mechanisms depending on the type of cells used. Transplanted ESCs, iPSCs, and NSCs can replace the missing brain cells in the infarcted area, while adult stem cells, such as MSCs and MNCs, provide trophic support to enhance selfrepair systems such as endogenous neurogenesis. Most preclinical studies of stem cell therapy for stroke have emphasized the need to enhance self-repair systems rather than to replace lost cells, regardless of the type of cells used.

\section{Clinical Trials of Stem Cell Research in Stroke}

Among all types of cells, bone marrowderived stem cells are used frequently in clinical trials with stroke (Table 1). We have successfully transplanted bone marrow derived mononuclear and mesenchymal stem cells in chronic stroke (33-35).

The functional benefits after neural transplantation are likely to be mediated by one of the following mechanisms, i.e., neurotransmitters released from the graft tissue act on the afferent deprived limb of the post synaptic receptors, release of the neurotrophic / growth factors, Brain-derived Neurotrophic Factor (BDNF), Glial-derived Neurotrophic Factor (GDNF), Nerve Growth Factor (NGF) acting as local pumps to support cell function and to prevent cascade of apoptosis, regenerating neuronal population further prevents subsequent cell death, reestablishment of local interneuronal connections and synaptic connectivity between the host and graft, cell differentiation and integration, improvement of regional oxygen tension $(36,37)$.

Our current stem cell trial investigates the paracrine mechanisms of mononuclear stem cells in chronic ischemic stroke, no serious adverse events were observed during the study.
There was no statistically significant clinical improvement between the groups (FM: 95\% CI 15.2-5.35, $\mathrm{p}=0.25$; mBI: $95 \%$ CI 14.3-4.5, $\mathrm{p}=0.31$ ). Vascular Endothelial Growth Factor (VEGF) and BDNF expression was found to be greater in one group compared to other (VEGF: 442.1 vs. $400.3 \mathrm{pg} / \mathrm{ml}, \mathrm{p}=0.67$; BDNF: $21.3 \mathrm{vs}$. $19.5 \mathrm{ng} / \mathrm{ml}$ ) without any statistically significant difference (38).

\section{Role of Noninvasive Brain Stimulation}

Noninvasive Brain Stimulation (NIBS) provides a valuable tool for interventional neurophysiology by modulating brain activity in a specific distributed, cortico-subcortical network $(39,40)$. Therapeutic utility of NIBS has been claimed in the literature for psychiatric disorders, such as depression, acutemania, bipolar disorders, schizophrenia, catatonia, post-traumatic stress disorder and neurologic diseases, such as stroke and parkinson's disease (41). The two most commonly used techniques for NIBS are Transcranial Magnetic Stimulation (TMS) and Transcranial Direct Current Stimulation (tDCS). TMS is a neurostimulation and neuromodulation application, whereas tDCS is a purely neuromodulatory intervention, both having their effect on the parameters of stimulation $(42,43)$.

Hsu et al conducted a meta-analysis on eighteen studies involving 392 patients on efficacy of TMS post-stroke(44). A significant effect size of 0.55 was found for motor outcome (95\% CI, 0.37-0.72) with subgroup analysis demonstrating more prominent effects on subcortical stroke (mean effect size $0.73 ; 95 \%$ CI, 0.44-1.02). Only 4 patients of the 18 articles included in this analysis reported adverse effects from rTMS (44). Low-frequency rTMS over the unaffected hemisphere may be more beneficial than high-frequency rTMS. Recent data suggest that intermittent theta-burst stimulation over the affected hemisphere might be a useful intervention (45). 
Cicinelli et al $(46,47)$ used focal TMS to map cortical representation via abductor digiti minimi (ADM) of the damaged hemisphere. It was observed that cortical excitability changed and there was an improvement in hand function. An ongoing research by our group which evaluates upregulation VEGF after acute ischemic stroke and its correlation with clinical recovery. It also examines the effects of rTMS $(1 \mathrm{~Hz})$ and correlates the expression of VEGF in stroke patients. The results of this study are awaited.

Plautz (48) and Kleim et al (49) showed that cortical stimulation can reorganize movement representations to peri-infarct areas in primates and rats after ischemic lesions to their motor cortices. The importance of contralesional activation during motor tasks involving the recovering hand or arm is not clear. The effects seem to range from neutral or positive consequence such as adaptive neuroplastic process to negative maladaption that may interfere with recovery.

In Transcranial Direct Current Stimulation (tDCS), low-amplitude direct currents are applied via scalp electrodes and penetrate the skull to enter the brain. Although the currents applied do not usually elicit action potentials, they modify the transmembrane neuronal potential and thus influence the level of excitability modulating the firing rate of individual neurons $(50,51)$.

Lindenberg et al (52) conducted a study on twenty chronic stroke patients which were randomly assigned to receive 5 consecutive sessions of either a) bihemispheric tDCS (anodal tDCS to upregulate excitability of ipsilesional motor cortex and cathodal tDCS to down-regulate excitability of contralesional motor cortex) with physiotherapy or b) sham stimulation with physiotherapy. The improvement of motor function was significantly greater in the real stimulation group (20.7\% in Fugl-Meyer and 19.1\% in Wolf Motor Function Test scores) when compared to the sham group (3.2\% in Fugl-Meyer and 6.0\% in Wolf Motor Function Test scores) lasting for 1 week.

Anodal stimulation increases the spontaneous firing rate and the excitability of cortical neurons by depolarizing the membranes where as cathodal stimulation leads to neuronal hyperpolarization resulting in a decrease of the neuronal firing rate and excitability. It was found that anodal (facilitatory) tDCS stimulation of the ipsilesional hemisphere was associated with greater behavioral gains (better response time) as compared to cathodal (inhibitory) tDCS of the contralesional hemisphere and was associated with increased activation within ipsilesional M1 and PMd (53, 54). This pattern of activity was first shown in animals receiving stimulation via epidural or intracerebral electrodes. Therefore, facilitatory stimulation of the ipsilesional hemisphere may lead to gains in motor function by increasing activation within ipsilesional motor areas (55).

Our group, in a randomized placebo controlled trial is evaluating the efficacy of tDCS and fluoxetine on chronic stroke on balance and gait. The patients are randomized to four groups; real and sham tDCS and fluoxetine groups with dual task exercise regime administered to all patients. This is an ongoing study with results awaited.

\section{Role of Mirror Therapy/Virtual Reality}

Mirror therapy was first described by Ramachandran in 1996 reporting its efficacy on pain reduction in armamputees and later was claimed to alleviate hemiparesis after stroke. A pilot study confirmed the positive effects of mirror therapy on facilitation in upper limb hemiparesis after stroke (56). Mirror therapy is defined as an intervention that uses a mirror to create a reflection of the non-paretic upper or lower limb, thus giving the patient visual feedback of normal movement of the paretic limb. In a systematic review, fourteen studies were included with 9-121 participants. It was 
found that mirror therapy had a significant effect on motor function (SMD 0.61;95\%; CI 0.22 to $1 ; p=0.002 ; I^{2}=75 \%$ ) (57). We also conducted a study with mirror therapy in chronic stroke patients using a web cam that captured the normal hand which was seen as affected in the laptop screen. Bilateral hand training were administered to patients and it was observed that MT improved hand function in FM and $\mathrm{mBI}$ scores along with an increased in laterality index (LI) in ipsilesional BA4 and 6(58).

\section{Role of Constraint Induced Movement Therapy (CIMT) and Electrical Stimulation}

CIMT has been investigated in 51 RCTs including 1784 patients with adult stroke, only 15 trials included patients within the first three months post-stroke. From systematic review (59), it is evident that original and modified versions of CIMT have a robust, clinically meaningful impact on patient's outcomes for arm-hand activities, self-reported hand use in daily life and basic ADL, making it one of the most effective interventions for the paretic limb post-stroke. It has also been reported that patients with poorer baseline behavior showed largest improvement on the wolf motor function test with increases in activation within the ipsilesional sensorimotor cortex during finger flexion/extension (60). Increased movement of the paretic upper extremity and decreased reliance on the non-paretic upper extremity are core features of CIMT (61).

Neuromuscular Electrical Stimulation (NMES) induces depolarization of peripheral neurons and subsequently elicits muscle contractions (62). It causes physiological changes after the stimulation, facilitating plastic changes during recovery and leading to improvement of voluntary functions. Functional Electrical Stimulation (FES) is one of the methods that uses electrical currents in stimulating the nerves connected to the paralyzed muscles in precise sequence and magnitude so that the outcome resembles functional tasks. FES aims to generate movements or functions, which mimic normal voluntary movements and therefore restore the functions (63). FES has some specific characteristics that makes it distinct from other forms of electrical stimulation. The frequency range of FES falls between 10 and $50 \mathrm{~Hz}$ and it directly stimulates the nerves or their motor points, not the muscle fibers. In 2002, Ada and Foongchomcheay (64) conducted a metaanalysis on the effect of electrical stimulation on shoulder outcomes after stroke. They showed that FES was superior to conventional therapy alone in the treatment of shoulder subluxation and arm motor function but was not effective in the treatment of pain early after stroke.

\section{Robotic Technology in Stroke}

The role of robotics in post-stroke rehabilitation has been investigated intensively. The robot-assisted rehabilitation of the upper limb in the acute and subacute post-stroke phase is successfully used an alternative to conventional mobilization, resulting in effective conventional therapy. Masiero et al (65) hypothesized that an optimal robotic training protocol for acute and subacute stroke patients should be divided in two stages: initial additional robotic training (first stage) followed by substitution of part of the conventional therapy with the robotic exercise (second stage) (66). The introduction of robotic systems into clinical practice is useful in promoting a costeffective use of human resources and the standardization of rehabilitation treatments. Hornby et al (67) performed a randomized controlled study comparing the effects of robotassisted gait training that uses exoskeleton devices and manual facilitation that uses an assist on gait function in patients with chronic stroke. Another investigator also studied the usefulness of robot-assisted therapy in patients with subacute stroke in a multicenter randomized trial. They concluded that the diversity of conventional gait training interventions appeared to be more effective than robot-assisted gait training for improving walking ability (68). A study by Lo et al 
recruited 127 chronic stroke patients reported that robot-assisted therapy and conventional therapy produced similar amounts of improvement after 12 weeks of treatment and after 36 weeks of therapy, the robot-assisted therapy achieved greater motor improvement than did conventional therapy (69).

\section{Pharmacological Agents}

Pharmacological therapy post-stroke may seem merely a chimera, translation of drugs from the laboratory to the clinic should be performed with caution, failure of which from the bench to bed side transition will be devastating. For example erythropoietin (EPO) was demonstrated in multiple clinical studies to provide therapeutic benefit. Phase II clinical trial was unsuccessful and had to be terminated because of high mortality and adverse events.

\section{Nitric Oxide (NO)}

$\mathrm{NO}$ is an "endothelial-derived relaxing factor" which is involved in maintaining endothelial cell integrity, as well as participating in hemodynamic homeostasis (70). NO is also a potent activator of soluble guanylatecyclase, the enzyme that converts GTP to cGMP, the delivery of NO donor increases cGMP levels within both ischemic and non-ischemic rat brains, suggesting a permissive role for $\mathrm{NO}$ in neurogenesis. The increased expression of neuronal NO synthase within the Subvenricular Zone (SVZ) during embryogenesis suggests an important role for the NO pathway in neurogenesis $(71,72)$. In addition to enhancing cGMP levels by augmenting NO availability, cGMP levels may also be increased by inhibiting its metabolism by the Phosphodiesterase-5 (PDE5) enzyme (73). Animals treated with sildenafil, a PDE5 inhibitor post-stroke achieved significant and substantial increase in neurological functional recovery (74). It demonstrated improved cerebral blood flow (CBF), neurogenesis and synaptogenesis following experimental stroke, even when therapy was delayed for up to 1 week.

\section{Gamma Amino Butyric Acid (GABA)}

Recovery after stroke involves remapping of the neuronal circuitry in the regions adjacent to the site of injury or the peri infarct zone (75). A pharmacological approach to re-establish functional neuronal connections that are lost during stroke could enhance current physical rehabilitation therapies. It is also proven that inhibiting GABAergic signaling pathways after stroke can improve locomotor function, suggesting a therapeutic approach that is less time sensitive than acute reperfusion therapies.

\section{Selective Serotonin Reuptake Inhibitors (SSRIs)}

Animal studies suggest that SSRIs may be involved in neurogenesis and activation of cortical motor areas modulating neuronal plasticity (76). These drugs are essential in maintaining sleep rhythm, and neurotransmitters levels within the brain and have been tried in stroke rehabilitation trials. A single dose of citalopram can normalize the balance in cortical excitability, as measured by transmagnetic stimulation. Patients more than 6 months after stroke, in a single dose cross over experiment with citalopram, showed improvement in hand dexterity as measured by the nine-hole peg test (77). A single dose of fluoxetine given 2-3 weeks after stroke showed improved motor skills on the none-hole peg test, and increased activation of the affected side on functional resonance imaging. A meta-analysis of randomized controlled trials on stroke patients treated with SSRI compared to usual care or sham; identified 52 trials for analysis and it was found that these drugs are associated with an improvement in functionality, neurological impairment, disability and depression (78).

\section{Minocycline}

Minocycline is the second generation tetracycline derivative known to have antiinflammatory effects independent of its antimicrobial action (79). Studies have shown 
that minocycline prevents microglial activation, and has notable beneficial effects in animal models of global and transient focal cerebral ischemia. The proposed mechanisms of minocycline include anti-inflammatory effects, reduction of microglial activation, MMP reduction, $\mathrm{NO}$ production and inhibition of apoptotic cell death (80). In a randomized single blinded study, we studied the effects of oral minocycline (200 mg/day for 5 days) poststroke versus placebo. Of 50 patients included in the trial, patients who received minocycline had better recovery in stroke outcome as noted on NIHSS, $\mathrm{mBI}$ and $\mathrm{mRS}$ scores (81).

\section{Cerebrolysin}

This is a peptide-based drug with potential to be used as a restorative agent. Multiple laboratories have demonstrated the safety and efficacy of this drug in the treatment of experimental stroke. It has been known to induce neurogenesis and angiogenesis in animal models of stroke and concomitantly enhances brain plasticity and recovery from stroke.

\section{Niaspan}

It is an extended release formulation of Niacin, proposed to be effective in reducing neurological deficits post-stroke by promoting axonal remodeling, angiogenesis and arteriogenesis (82). Niacin-induced increase in synaptic plasticity and axon growth may be mediated by the up-regulation in the BDNF-TrkB axis (Cui et al, 2010). In the mature nervous system, BDNF/TrkB plays an important role in regulating neuronal migration, differentiation, synaptic remodeling, and survival. Niacin treatment after stroke significantly increases BDNF/TrkB expression both in the ischemic brain and in primary cortical neuron (PCN) cultures (82). It has also been proven that combination of Niaspan with Simvastatin helped improve overall functional outcome significantly and decreased axonal damage and density (83).

\section{Neuroimaging Provides Insight into Neuroplasticity}

A wide number of neuroimaging methods exist for evaluating the state of Central Nervous System (CNS) function and structure after stroke. Brain function can be measured using functional Magnetic Resonance Imaging (fMRI), Positron Emission Tomography (PET), electroencephalography (EEG), magnetoencephalography (MEG), Transcranial Magnetic Stimulation (TMS) and near infrared spectroscopy (84). These techniques measure the volume of regional brain activation, the magnitude of activation and the balance of activation across hemispheres, often reported as a laterality index, during a task or at rest. Each technique has its merits and limits, MRI involves no isotopes and can also measure Cerebral Blood Flow (CBF) and angiography; PET can be used to measure CBF, metabolism, neurochemistry, and receptor kinetics; and TMS and MEG have temporal resolution at the millisecond level. Diffusion Tensor Imaging (DTI) is an MRI method for examining white matter integrity via measures such as Fractional Anisotropy (FA) enabling delineation of the anatomical connectivity of white-matter pathways (85).

An increasing number of studies have examined the mechanisms of spontaneous recovery after stroke. Studies have elucidated many of the cellular and molecular events, both near and remote from the lesion, that underlie spontaneous post-stroke improvements. These results are concordant with many of the findings from noninvasive neuroimaging methods in human subjects mentioned above.

\section{Conclusion}

Neurorestoration is a concept that has been proven emphatically in several experimental models and clinical studies of stroke. Elucidating the underlying mechanisms of cellbased, pharmacological and rehabilitative therapies is of primary interest and crucial for 
translation of treatments to clinical use. The knowledge must provide an impetus for the development of superior, advanced \& costeffective neurorestorative interventions that will enhance stroke recovery.

\section{References}

1. Zhang ZG, Chopp M (2009). Neurorestorative therapies for stroke: underlying mechanisms and translation to the clinic. Lancet Neurol 8(5):491-500.

2. Hacke W, Kaste M, Bluhmki E, et al (2008). Thrombolysis with alteplase 3 to 4.5 hours after acute ischemic stroke. NEJM 359(13): 1317-1329.

3. Grotta JC, Jacobs TP, Koroshetz WJ, Moskowitz MA (2008). Stroke program review group: an interim report. Stroke 39:1364-1370.

4. Burke E, Cramer SC (2013). Biomarkers and predictors of restorative therapy effects after stroke. Curr Neurol Neurosci Rep13: 329.

5. Kawamata T, Speliotes EK, Finklestein SP (1997). The role of polypeptide growth factors in recovery from stroke. In: Brain Plasticity. Freund HJ, Sabel BA, Witte OW, eds. Philadelphia : Lippincott-Raven, 377-382.

6. Kononen M, Tarkka IM, Niskanen E, et al (2012). Functional MRI and motor behavioral changes obtained with constraint-induced movement therapy in chronic stroke. Eur J Neurol 19(4):578-586.

7. Cramer SC (2008). Repairing the human brain after stroke. II Restorative therapies. Annal Neurol 63(5):549-560.
8. Nudo RJ (2013). Recovery after braininjury : mechanisms and principles. Front Hum Neurosci 7:1-9.

9. Young HE, Black AC Jr (2004). Adult stem cells. Anat Rec A Discov Mol Cell Evol Biol 276: 75-102.

10. Seaberg RM, van der Kooy D (2003). Stem and progenitor cells: the premature desertion of rigorous definitions. Trends Neurosci 26: 125-131.

11. Jaenisch R, Young R (2008). Stem cells, the molecular circuitry of pluripotency and nuclear reprogramming. Cell 132: 567-582.

12. Tandon PN (2007). Brain cells--recently unveiled secrets: their clinical significance. Neurol India 55: 322-327.

13. McKay R (1997). Stem cells in the central nervous system. Science 276: 66-71.

14. Takahashi K, Okita K, Nakagawa M, Yamanaka S (2007). Induction of pluripotent stem cells from fibroblast cultures. Nat Protoc 2: 3081-3089.

15. Yamanaka S (2007). Strategies, new developments in the generation of patientspecific pluripotent stem cells. Cell Stem Cell 1:39-49.

16. Hess DC, Borlongan CV (2008). Stem cells and neurological diseases. Cell Prolif 41 Suppl 1: 94-114.

17. Yu G, Borlongan CV, Stahl CE, et al (2009). Systemic delivery of umbilical cord blood cells for stroke therapy: a review. Restor Neurol Neurosci 27:41-54.

18. Park CH, Minn YK, Lee JY, et al (2005). In vitro and in vivo analyses of human embryonic stem cell-derived dopamine neurons. JNeurochem 92: 1265-1276. 
19. Perrier AL, Tabar V, Barberi $\mathrm{T}$, et al (2004). Derivation of midbrain dopamine neurons from human embryonic stem cells. Proc Natl Acad Sci USA 101:25432548.

20. Patkar S, Tate R, Modo M, Plevin R, Carswell HV (2012). Conditionally immortalised neural stem cells promote functional recovery and brain plasticity after transient focal cerebral ischemia in mice. Stem Cell Res 8:14-25.

21. Tabar V, Panagiotakos G, Greenberg ED, et al (2005). Migration and differentiation of neural precursors derived from human embryonic stem cells in the rat brain. Nat Biotechnol 23:601-606.

22. Vroemen M, Aigner L, Winkler J, Weidner N (2003). Adult neural progenitor cell grafts survive after acute spinal cord injury and integrate along axonal pathways. Eur JNeurosci 18: 743-751.

23. Evans MJ, Kaufman MH (1981). Establishment in culture of pluripotential cells from mouse embryos. Nature 292:154-156.

24. Lie DC, Dziewczapolski G, Willhoite AR, et al (2002). The adult substantianigra contains progenitor cells with neurogenic potential. JNeurosci 22:6639-6649.

25. Morrison SJ, Uchida N, Weissman IL (1995). The biology of hematopoietic stem cells. Annu Rev Cell DevBiol 11: 3571.

26. Domen J, Weissman IL (1999). Selfrenewal, differentiation or death: regulation and manipulation of hematopoietic stem cell fate. Mol Med Today 5: 201-208.

27. Ploemacher RE (1997). Stem cells: characterization and measurement. Bailliere's Clin Haematol 10: 429-444.
28. Bianco P, Riminucci M, Gronthos S, Robey PG (2001). Bone marrow stromal stem cells: nature, biology, and potential applications. Stem Cells 19: 180-192.

29. Kolf CM, Cho E, Tuan RS (2007). Mesenchymal stromal cells. Biology of adult mesenchymal stem cells: regulation of niche, self-renewal and differentiation. Arthritis Res Ther 9:204.

30. Jiang $\mathrm{Y}$, Jahagirdar BN, Reinhardt RL, et al (2002). Pluripotency of mesenchymal stem cells derived from adult marrow. Nature 418:41-49.

31. Prockop DJ (1997). Marrow stromal cells as stem cells for nonhematopoietic tissues. Science 276: 71-74.

32. Yu F, Li Y, Morshead CM (2013). Induced pluripotent stem cells for the treatment of stroke: the potential and the pitfalls. Current Stem Cell Res \& Therapy 8(5):407-414.

33. Bhasin A, Srivastava MV, Mohanty S, Bhatia R, Kumaran SS (2013). Stem cell therapy: a clinical trial of stroke. Clin Neurol Neurosurg 115:1003-1008.

34. Bhasin A, Srivastava MV, Bhatia R, et al (2012). Autologous intravenous mononuclear stem cell therapy in chronic ischemic stroke. JSRM 8:181-189.

35. Bhasin A, Srivastava MV, Kumaran SS, et al (2011). Autologous mesenchymal stem cells in chronic stroke. Cerebrovasc Dis Extra 1: 93-104.

36. Meamar R, Dehghani L, Ghasemi L, Khorvash F, Shaygannejad V (2013). Stem cell therapy in stroke: a review of literature. Int J Prev Med 4(2):S139. 
37. Bang YO (2016). Clinical trials of adult stem cell therapy in patients with ischemic stroke. JClin Neurol 12(1):14-20.

38. Bhasin A, Srivastava MV, Mohanty S, et al (2016). Paracrine mechanisms of intravenous bone marrow-derived mononuclear stem cells in chronic ischemic stroke. Cerebrovasc Dis Extra 6:107-119

39. Auriat AM, Neva JL, Peters S, Ferris JK, Boyd LA(2015). A review of transcranial magnetic stimulation and multimodal neuroimaging to characterize post-stroke neuroplasticity. Front Neurol 6:226-231.

40. Bindman LJ, Lippold OC, Redfearn JW (1964). Relation between the size and form of potentials evoked by sensory. $J$ Physiol 171:1-25.

41. Hoyer EH, Celhik PA (2011). Understanding and enhancing motor recovery after stroke using transcranial magnetic stimulation. Restor Neurol Neurosc 29(6):395-409.

42. Reato D, Rahman A, Bikson M, Parra LC (2010). Low-intensity electrical stimulation affects network dynamics by modulating population rate and spike timing. JNeurosci 30(45) :15067-15079.

43. Corti M, Pattern C, Triggs W (2012). Repetitive transcranial magnetic stimulation of motor cortex after stroke. Arch Phy Med Rehabil 91(3):254-270.

44. Hsu WY, Cheng $\mathrm{CH}$, Liao KK, Lee IH, Lin YY (2012). Effects of repetitive transcranial magnetic stimulation on motor functions in patients with stroke: a meta-analysis. Stroke 43 : 1849-1857

45. Kubis N (2016). Non-Invasive Brain Stimulation to Enhance Post-Stroke Recovery. Front Neural Circuits 10:56-62.
46. Cicinelli P, Pasqualetti P, Zaccagnini M (2006). Imagery-induced cortical excitability changes in stroke: a transcranial magnetic stimulation study. Cereb Cortex 16(2):247-253.

47. Cicinelli P, Pasqualetti P, Zaccagnini M (2003). Interhemispheric asymmetries of motor cortex excitability in the post acute stroke stage: a paired pulse transcranial stimulation study. Stroke 34(11):26532658.

48. Plautz EJ, Barbay S, Frost SB, et al (2003). Post-infarct cortical plasticity and behavioral recovery using concurrent cortical stimulation and rehabilitative training: a feasibility study in primates. Neurological Research 25: 801-810.

49. Kleim JA, Kleim ED, Cramer SC (2007). Systematic assessment of traininginduced changes in corticospinal output to hand using frameless stereotaxic transcranial magnetic stimulation. Nature Protocols 2:1675-1684.

50. Gomez A, Schjetnan P, Faraji J, Gerlinde A, Tatsuno MM, Luczak A (2013). Transcranial Direct Current Stimulation in Stroke Rehabilitation: A Review of Recent Advancements. Review. Stroke Research and Treatment ; article ID170456.

51. Nitsche MA, Liebetanz D, Lang N, et al (2003). Safety criteria for transcranial direct current stimulation (tDCS) in humans. Clin Neurophysiol 11:2220-2223.

52. Leindenberg R, Rengha V, Zhu LL, Nair D, Schlaug G (2010). Bihemispheric brain stimulation facilitates motor recovery in chronic stroke patients. Neurology 75:2176-2184. 
53. Kim DY, Ohn SH, Yang EJ, Park CI, Jung KJ (2009). Enhancing motor performance by anodal transcranial direct current stimulation in subacute stroke patients. $A J$ Phy Med Rehabil 88:829-836.

54. Fregni S, Boggio PS, Mansur CG, et al (2005). Transcranial direct current stimulation of the unaffected hemisphere in stroke patients. Neuro Report 16:15511555.

55. Webster BR, Celnik PA, Cohen LG (2006). Noninvasive brain stimulation in stroke rehabilitation. NeuroRx 3:474-481.

56. Ramachandran VS, Altschuler EL, Stone L, Al-Aboudi M, Schwartz E, Siva N (1999). Can mirrors alleviate visual hemineglect? Medical Hypotheses 52(4):303-305.

57. Dohle C, Pullen J, Nakaten A, Kust J, Rietz C, Karbe H (2009). Mirror therapy promotes recovery from severe hemiparesis: a randomized controlled trial. Neurorehabil Neural Repair 23(3):209-217.

58. Bhasin A, Srivastava MV, Kumaran SS, Bhatia R, Mohanty S (2012). Neural interface of mirror therapy in chronic stroke. A functional magnetic resonance imaging study. Neurology India 60(6): 570-576.

59. Kwakkel G, Veerbeek JM, Wegen EEM, Wolf SL (2015). Constraint-Induced Movement Therapy after Stroke. Lancet Neurol 14(2):224-234.

60. Reiss A, Wolf S, Hammel E, McLeod E, Williams E (2012). Constraint-Induced Movement Therapy (CIMT): Current Perspectives and Future Directions. Stroke Research and Treatment 8:159391159396.
61. Nijland R, Kwakkel G, Bakers J, van Wegen E (2011). Constraint-induced movement therapy for the upper paretic limb in acute or sub-acute stroke: a systematic review. Int $J$ Stroke 6(5):425-433.

62. Sheffler LR, Chae J ( $\begin{aligned} & 2 \\ & 0\end{aligned}$ Neuromuscular electrical stimulation in neurorehabilitation. Muscle \& Nerve 35:562-590.

63. Quandt F, Hummel FC (2014). The influence of functional electrical stimulation on hand motor recovery in stroke patients: a review. Exp Transl Stroke Med 6:9-15.

64. Ada L, Foongchomcheay A (2002). Efficacy of electrical stimulation in preventing or reducing subluxation of the shoulder after stroke: a meta-analysis. Aust J Physiother 48(4) : 257-267.

65. Masiero S, Celia A, Rosati G, Armani M (2007). Robotic-assisted rehabilitation of the upper limb after acute stroke. Arch Phys Med Rehabil 88(2): 142-147.

66. Masiero S, Celia A, Armani M, Rosati G (2006). A novel robot device in rehabilitation of post-stroke hemiplegic upper limbs. Aging Clin Exp Res 18(6):531-535.

67. Hornby TG, Campbell DD, Kahn JH, Demott T, Moore JL, Roth HR (2008). Enhanced gait-related improvements after therapist-versus robotic-assisted locomotor training in subjects with chronic stroke: a randomized controlled study. Stroke 39(6): 1786-1792. 
68. Mayr A, Kofler M, Quirbach E, Matzak H, Fröhlich K, Saltuari L (2007). Prospective, blinded, randomized crossover study of gait rehabilitation in stroke patients using the Lokomat gait orthosis. Neurorehabil Neural Repair 21(4):307-314.

69. Lo AC, Guarino PD, Richards LG, et al (2010). Robot-assisted therapy for longterm upper-limb impairment after stroke. NEnglJMed 362:1772-1783.

70. Palmer RM, Ferrige AG, Moncada S (1987). Nitric oxide release accounts for the biological activity of endotheliumderived relaxing factor. Nature 327: 524526.

71. Bredt DS, Snyder SH (1994). Nitric oxide: a physiologic messenger molecule. Annu Rev Biochem 63: 175-195.

72. Zhang RL, Zhang Z, Zhang L, et al (2006). Delayed treatment with sildenafil enhances neurogenesis and improves functional recovery in aged rats after focal cerebral ischemia. J Neurosci Res 83: 1213-1219.

73. Berends HI, Nijlant JM, Movig KL, et al (2009). The clinical use of drugs influencing neurotransmitters in the brain to promote motor recovery after stroke; a Cochrane systematic review. Eur J Phys Rehabil Med 45: 621-630.

74. Clarkson AN, Huang BS, Macisaac SE, Mody I, Carmichael ST (2010). Reducing excessive GABA-mediated tonic inhibition promotes functional recovery after stroke. Nature 468: 305-309.
75. Acler M, Robol E, Fiaschi A, Manganotti P (2009). A double blind placebo RCT to investigate the effects of serotonergic modulation on brain excitability and motor recovery in stroke patients. J Neurol 256(7): 1152-1158.

76. Pariente J, Loubinoux I, Carel C, et al (2001). Fluoxetine modulates motor performance and cerebral activation of patients recovering from stroke. Ann Neurol 50(6): 718-729.

77. Chollet F, Tardy J, Albucher JF, et al (2011). Fluoxetine for motor recovery after acute ischemic stroke (FLAME): a randomized placebo-controlled trial. Lancet Neurol 10(2): 123-130.

78. Mead GE, Hsieh CF, Lee R, et al (2010). Selective serotonin reuptake inhibitors (SSRIs) for stroke recovery. Cochrane Database Syst Rev 310(10):1066-1067.

79. Fagan SC, Waller JL, Nichols FT, et al (2010). Minocycline to improve neurologic outcome in stroke (minos): A dose-finding study. Stroke 41(10): 22832287.

80. Murata Y, Rosell A, Scannevin RH, et al (2008). Extension of the thrombolytic time window with minocycline in experimental stroke. Stroke 39(12): 33723377.

81. Padma MV, Bhasin A, Bhatia R, et al (2012). Efficacy of minocycline in acute ischemic stroke: A single-blinded, placebocontrolled trial. Neurol India 60(1): 23-28

82. Yan T, Chopp M, Ye X, et al (2012). Niaspan increases axonal remodeling after stroke in type 1 diabetes rats. Neurobiol Dis 46:157-164. 
83. Shehadah A, Chen J, Cui X, Roberts C, Lu M, Chopp M (2010). Combination treatment of experimental stroke with Niaspan and Simvastatin, reduces axonal damage and improves functional outcome. JNeurol Sci 94: 107-111.

84. Hosp JA, Luft AR (2011). Cortical plasticity during motor learning and recovery after ischemic stroke. Neural Plast 2011(2):871296.
85. Westlake KP, Nagarajan SS (2011). Functional connectivity in relation to motor performance and recovery after stroke. Front Syst Neurosci 5(2):8-13. 